\title{
PERAN PENDIDIKAN MUATAN LOKAL TERHADAP PEMBANGUNAN KARAKTER BANGSA
}

\author{
Durrotun Nafisah*
}

\begin{abstract}
Abstrak
emakin meningkatnya peristiwa yang terjadi pada bangsa Indonesia, antara lain tingginya tingkat kriminaitas, korupsi, penegakan hukum yang jauh dari $\checkmark$ keadilan, dan terorisme. Menunjukkan bahwa Indonesia mengalami krisis etika dan krisis kepercayaan diri. Berdasarkan kenyataan tersebut, pendidikan nilai moral memang sangat diperlukan pada bangsa ini. Pelaksanaan pendidikan muatan lokal mampu membangun karakter bangsa, karena pelaksanaan muatan lokal benar-benar memperhatikan karakteristik lingkungan dan kebudayaan lokal. Konsep muatan lokal sesuai dengan konsep trikon yang dikemukakan oleh Ki Hajar Dewantara yaitu salah satunya konsentris, yang berarti setelah bersatu dan berkomunikasi dengan bangsa-bangsa lain di dunia, jangan kehilangan kepribadian sendiri. Muatan lokal mampu membentuk karakter bangsa Indonesia yang asli karena sebagai penguat sumber daya manusia Indonesia akan kecintaan dan nilai lokal daerah sebagai bentuk pertahanan diri dalam arus globalisasi. Muatan lokal dimasukkan dalam kurikulum karena dilandasi kenyataan bahwa Indonesia memiliki beraneka ragam adat istiadat, kesenian, tata acara, tata krama pergaulan, bahasa dan pola kehidupan yang diwariskan secara turun-temurun dari nenek moyang bangsa Indonesia. Hal tersebut menunjukkan bahwa muatan lokal mampu membangun karakter bangsa sesuai dengan ciri khas dan jati diri bangsa. Tulisan ini berupaya menjelaskan peran pendidikan muatan lokal terhadap pembangunan karakter bangsa dengan metode conceptual paper, yaitu melalui kajian bersifat kualitatif melalui pengumpulan jurnal deskriptif dan literatur.
\end{abstract}

Kata Kunci: Pendidikan, Muatan Lokal, Karakter Bangsa

* Mahasiswa Prodi PPKn IKIP PGRI Madiun 


\section{PENDAHULUAN}

Dalam UU RI No 20 tahun 2003 tentang Sistem Pendidikan Nasional, merumuskan fungsi dan tujuan pendidikan Nasional yang harus digunakan dalam mengembangkan upaya pendidikan di Indonesia pasal 3 UU Sikdiknas menyebutkan "Pendidikan Nasional berfungsi mengembangkan dan membantu watak serta peradaban bangsa yang bermartabat dalam rangka mencerdaskan bangsa. Bertujuan untuk berkembangnya potensi, peserta didik agar menjadi manusia yang beriman yang bertakwa kepada Tuhan Yang Maha Esa, berakhlak mulia, sehat, berilmu, cakap, kreatif, mandiri dan menjadi warga negara yang demokratis serta bertanggung jawab". Tujuan Pendidikan Nasional merupakan rumusan mengenai kualitas manusia modern yang harus dikembangkan oleh setiap satuan pendidikan. Oleh sebab itu rumusan tujuan pendidikan nasional menjadi dasar pengembangan pendidikan karakter bangsa.

Nampaknya peristiwa akhirakhir ini yang dapat mengkawatirkan kehidupan bangsa, telah menjadi penyebab mendesakkan dihidupkan kembali pembangunan karakter bangsa. Peristiwa itu antara lain: kenakalan remaja; korupsi yang begitu meluas dan menggila; budaya kurang santun dalam mengungkapkan perbedaan pendapat seperti sering terlihat di DPR; tawuran dan kekerasan di lingkungan pendidikan menengah dan di PT; konflik horizontal di tengah masyarakat yang sering memakan korban banyak jiwa. Selain itu tantangan globalisasi dalam berbagai aspek kehidupan, juga menuntut disikapi dengan karakter yang lebih kuat.

Secara umum untuk mewujudkan pendidikan karakter bangsa dapat dilakukan melalui pendidikan formal, non formal, dan informal yang saling melengkapi dan mempercayai dan diatur dalam peraturan dan undang-undang. Saat ini hampir di setiap sekolah formal SD, SM, dan PT mulai diusahakan berbagai program pendidikan karakter bangsa. Berbagai model pendidikan karakter bangsa dicoba, seperti pendidikan karakter lewat suatu mata pelajaran tersendiri, lewat semua mata pelajaran sekolah, lewat kegiatan kokurikuler dan 
ekstrakurikuler. Banyak kegiatan outbound dan live in digunakan untuk membantu pendidikan karakter bangsa pada peserta didik (Suparno, P., 2010).

Salah satu strategi yang dapat digunakan dalam membentuk karakter bangsa adalah pengembangan kurikulum muatan lokal (MULOK) yang sudah dilakukan dalam pendidikan di Indonesia. Pengembangan MULOK merupakan pengembangan konsep pendidikan yang sesuai dengan konsep dari Ki Hajar Dewantara yaitu Trikon. Pendidikan menurut Ki Hajar Dewantara merupakan proses pembudayaan yakni suatu usaha memberikan nilai-nilai luhur kepada generasi baru dalam masyarakat yang tidak hanya bersifat pemeliharaan tetapi juga dengan maksud memajukan serta memperkembangkan kebudayaan menuju ke arah keluhuran budaya manusia. Upaya kebudayaan (pendidikan) dapat ditempuh dengan sikap (laku) yang dikenal dengan teori Trikon, yaitu kontinuitas berarti bahwa garis hidup sekarang harus merupakan lanjutan dari kehidupan pada zaman lampau berikut penguasaan unsur tiruan dari kehidupan dan kebudayaan bangsa lain; konvergensi berarti harus menghindari hidup menyendiri, terisolasi dan mampu menuju ke arah pertemuan antar bangsa dan komunikasi antar negara menuju kemakmuran bersama atas dasar saling menghormati, persamaan hak, dan kemerdekaan masingmasing; dan konsentris berarti setelah bersatu dan berkomunikasi dengan bangsabangsa lain di dunia, jangan kehilangan kepribadian sendiri. Bangsa Indonesia adalah masyarakat merdeka yang memiliki adat istiadat dan kepribadian sendiri. Meskipun kita bertitik pusat satu, namun dalam lingkaran yang konsentris itu kita masih tetap memilik lingkaran sendiri yang khas yang membedakan Negara kita dengan Negara lain.

Konsep konsentris yang dikemukakan oleh Ki Hajar Dewantara merupakan dasar pengembangan kurikulum melalui muatan lokal. Muatan lokal diberikan dalam rangka usaha pengenalan pemahaman dan pewarisan nilai karakteristik daerah kepada peserta didik. Kedudukan muatan lokal dalam kurikulum bukanlah mata pelajaran 
yang berdiri sendiri, tetapi merupakan mata pelajaran terpadu, yaitu bagian dari mata pelajaran yang sudah ada. Melalui muatan lokal yang diterapkan di sekolah, diharapkan peserta didik dapat meningkatkan kecintaannya terhadap budaya daerahnya dan menanamkan nilai sosio kultural yang melingkupi peserta didik. Pemahaman nilai karakteristik daerah kepada peserta didik diharapkan dapat membentuk karaktek peserta didik. Dengan begitu peserta didik akan menjadikan arus global menjadi tambahan kekayaan nilai sosio kultural tanpa menghilangkan nilai budaya daerah.

Derasnya arus globalisasi, modernisasi dan ketatnya puritanisme dikhawatirkan dapat mengakibatkan terkikisnya rasa kecintaan terhadap kebudayaan lokal. Sehingga kebudayaan lokal yang merupakan warisan leluhur terinjak-injak oleh budaya asing. Bangsa Indonesia lebih bangga dengan karya-karya asing, dan gaya hidup yang kebarat-baratan dibandingkan dengan kebudayaan lokal di daerah mereka sendiri. Padahal, bahasa sebagai alat dalam menyampaikan pembelajaran sangat besar pengaruhnya terhadap pembentukan karakter bangsa. Modernisasi mengikis budaya lokal menjadi kebarat-baratan, sedangkan puritanisme sering menganggap budaya sebagai praktik sinkretis yang harus dihindari. Menurut penulis, sepanjang tidak bertentangan dengan norma, budaya lokal harus selalu dipertahankan untuk memperkuat karakter anak bangsa. Padahal, jika kita memahami, kebudayaan lokal di daerah tidak kalah saing dengan budaya-budaya asing yang belum kita kenal.

Prof. Dr. M. Surya mengatakan bahwa pembelajaran sejati bersifat nyata, dekat, dikenal, alami dan natural, yang merupakan kesatuan dari konsep MULOK. Pembelajaran sejati inilah yang akan mewujudkan SDM berkualitas dan siap menghadapi tantangan dan peluang bangsa. Dalam tulisan ini akan dibahas apa peran pendidikan muatan lokal terhadap pembangunan karakter bangsa tersebut.

\section{NILAI KARAKTER BANGSA}

Penguatan pendidikan moral (moral education) atau pendidikan karakter (character education) dalam konteks sekarang sangat relevan 
untuk mengatasi krisis moral yang sedang melanda di negara kita. Krisis tersebut antara lain berupa meningkatnya pergaulan bebas, maraknya angka kekerasan anak-anak dan remaja, kejahatan terhadap teman, pencurian remaja, kebiasaan menyontek, penyalahgunaan obatobatan, pornografi, dan perusakan milik orang lain sudah menjadi masalah sosial yang hingga saat ini belum dapat diatasi secara tuntas, oleh karena itu betapa pentingnya pendidikan karakter.

Oleh Kementerian Pendidikan dan Kebudayaan (Kemdikbud), telah dirumuskan 18 nilai pendidikan budaya dan karakter bangsa yang diharapkan untuk disampaikan kepada peserta didik dalam pendidikan formal. Nilai-nilai itu adalah:

Tabel 1. Nilai Pendidikan Budaya dan Karakter Bangsa Menurut Kemdikbud

\begin{tabular}{|l|l|l|}
\hline No & Nilai Karakter & \multicolumn{1}{|c|}{ Deskripsi } \\
\hline 1 & Religius & Sikap dan perilaku \\
& & yang patuh dalam \\
& & melaksanakan \\
& & ajaran agama yang \\
& & dianutnya, toleran \\
& & terhadap \\
& & pelaksanaan ibadah \\
\hline
\end{tabular}

\begin{tabular}{|c|c|c|}
\hline & & $\begin{array}{l}\text { agama lain, dan } \\
\text { hidup rukun dengan } \\
\text { pemeluk agama } \\
\text { lain. }\end{array}$ \\
\hline 2 & Jujur & $\begin{array}{lr}\text { Perilaku } & \text { yang } \\
\text { didasarkan } & \text { pada } \\
\text { upaya } & \text { menjadikan } \\
\text { dirinya } & \text { sebagai } \\
\text { orang yang } & \text { selalu } \\
\text { dapat dipercaya } \\
\text { dalam perkataan, } \\
\text { tindakan, } \\
\text { pekerjaan. }\end{array}$ \\
\hline 3 & Toleransi & $\begin{array}{l}\text { Sikap dan tindakan } \\
\text { yang menghargai } \\
\text { perbedaan agama, } \\
\text { suku, etnis, } \\
\text { pendapat, sikap, } \\
\text { dan tindakan orang } \\
\text { lain yang berbeda } \\
\text { dari dirinya. }\end{array}$ \\
\hline 4 & Disiplin & $\begin{array}{l}\text { Tindakan yang } \\
\text { menunjukkan } \\
\text { perilaku tertib dan } \\
\text { patuh pada berbagai } \\
\text { ketentuan dan } \\
\text { peraturan. }\end{array}$ \\
\hline 5 & Kerja Keras & $\begin{array}{l}\text { Tindakan yang } \\
\text { menunjukkan } \\
\text { perilaku tertib dan } \\
\text { patuh pada berbagai } \\
\text { ketentuan dan } \\
\text { peraturan. }\end{array}$ \\
\hline 6 & Kreatif & $\begin{array}{l}\text { Berpikir dan } \\
\text { melakukan sesuatu } \\
\text { untuk menghasilkan } \\
\text { cara atau hasil baru } \\
\text { dari sesuatu yang }\end{array}$ \\
\hline
\end{tabular}




\begin{tabular}{|c|c|c|}
\hline & & telah dimiliki. \\
\hline 7 & Mandiri & $\begin{array}{l}\text { Sikap dan perilaku } \\
\text { yang tidak mudah } \\
\text { tergantung pada } \\
\text { orang lain dalam } \\
\text { menyelesaikan } \\
\text { tugas-tugas. }\end{array}$ \\
\hline 8 & Demokratis & 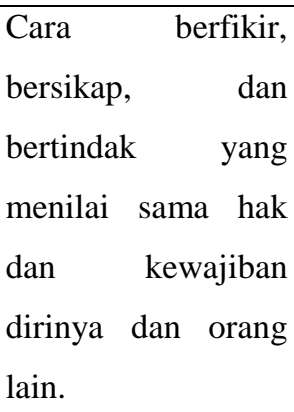 \\
\hline 9 & $\begin{array}{l}\text { Rasa Ingin } \\
\text { Tahu }\end{array}$ & $\begin{array}{l}\text { Sikap dan tindakan } \\
\text { yang } \\
\text { berupaya } \\
\text { mengetahui } \\
\text { mendalam lebih } \\
\text { meluas dari sesuatu } \\
\text { yang dipelajarinya, } \\
\text { dilihat, } \\
\text { didengar. }\end{array}$ \\
\hline 10 & $\begin{array}{l}\text { Semangat } \\
\text { Kebangsaan }\end{array}$ & $\begin{array}{l}\text { Cara berpikir, } \\
\text { bertindak, dan } \\
\text { berwawasan yang } \\
\text { menempatkan } \\
\text { kepentingan bangsa } \\
\text { dan negara di atas } \\
\text { kepentingan diri } \\
\text { dan kelompoknya. }\end{array}$ \\
\hline 11 & $\begin{array}{l}\text { Cinta Tanah } \\
\text { Air }\end{array}$ & $\begin{array}{l}\text { Cara berpikir, } \\
\text { bertindak, dan } \\
\text { berwawasan yang } \\
\text { menempatkan } \\
\text { kepentingan bangsa } \\
\text { dan negara di atas } \\
\text { kepentingan diri }\end{array}$ \\
\hline
\end{tabular}

\begin{tabular}{|c|c|c|}
\hline & & dan kelompoknya. \\
\hline 12 & $\begin{array}{l}\text { Menghargai } \\
\text { Prestasi }\end{array}$ & $\begin{array}{lr}\text { Sikap dan tindakan } \\
\text { yang mendorong } \\
\text { dirinya untuk } \\
\text { menghasilkan } \\
\text { sesuatu yang } \\
\text { berguna bagi } \\
\text { masyarakat, dan } \\
\text { mengakui, serta } \\
\text { menghormati } \\
\text { keberhasilan } & \\
\text { lain. } & \end{array}$ \\
\hline 13 & $\begin{array}{l}\text { Bersahabat/Ko } \\
\text { munikatif }\end{array}$ & $\begin{array}{lr}\text { Sikap dan tindakan } \\
\text { yang mendorong } \\
\text { dirinya untuk } \\
\text { menghasilkan } \\
\text { sesuatu yang } \\
\text { berguna bagi } \\
\text { masyarakat, dan } \\
\text { mengakui, serta } \\
\text { menghormati } \\
\text { keberhasilan } \\
\text { lain. orang }\end{array}$ \\
\hline 14 & Cinta Damai & $\begin{array}{l}\text { Sikap dan tindakan } \\
\text { yang mendorong } \\
\text { dirinya untuk } \\
\text { menghasilkan } \\
\text { sesuatu yang } \\
\text { berguna bagi } \\
\text { masyarakat, dan } \\
\text { mengakui, serta } \\
\text { menghormati } \\
\text { keberhasilan } \\
\text { lain. }\end{array}$ \\
\hline 15 & $\begin{array}{l}\text { Gemar } \\
\text { Membaca }\end{array}$ & $\begin{array}{l}\text { Kebiasaan } \\
\text { menyediakan waktu } \\
\text { untuk membaca } \\
\text { berbagai bacaan }\end{array}$ \\
\hline
\end{tabular}




\begin{tabular}{|c|c|c|}
\hline & & $\begin{array}{l}\text { yang memberikan } \\
\text { kebajikan bagi } \\
\text { dirinya. }\end{array}$ \\
\hline 16 & $\begin{array}{l}\text { Peduli } \\
\text { Lingkungan }\end{array}$ & $\begin{array}{l}\text { Sikap dan tindakan } \\
\text { yang selalu } \\
\text { berupaya mencegah } \\
\text { kerusakan pada } \\
\text { lingkungan alam di } \\
\text { sekitarnya, dan } \\
\text { mengembangkan } \\
\text { upaya-upaya untuk } \\
\text { memperbaiki } \\
\text { kerusakan alam } \\
\text { yang sudah terjadi. }\end{array}$ \\
\hline 17 & Peduli Sosial & $\begin{array}{l}\text { Sikap dan tindakan } \\
\text { yang selalu ingin } \\
\text { memberi bantuan } \\
\text { pada orang lain dan } \\
\text { masyarakat yang } \\
\text { membutuhkan. }\end{array}$ \\
\hline 18 & $\begin{array}{l}\text { Tanggung } \\
\text { Jawab }\end{array}$ & $\begin{array}{l}\text { Sikap dan perilaku } \\
\text { seseorang untuk } \\
\text { melaksanakan tugas } \\
\text { dan kewajibannya, } \\
\text { yang seharusnya dia } \\
\text { lakukan, terhadap } \\
\text { diri sendiri, } \\
\text { masyarakat, } \\
\text { lingkungan (alam, } \\
\text { sosial dan budaya), } \\
\text { negara dan Tuhan } \\
\text { Yang Maha Esa. }\end{array}$ \\
\hline
\end{tabular}

Pendidikan karakter telah menjadi perhatian berbagai negara dalam rangka mempersiapkan generasi yang berkualitas, bukan hanya untuk kepentingan individu warga negara, tetapi juga untuk warga masyarakat secara keseluruhan. Pendidikan karakter dapat diartikan sebagai the deliberate us of all dimensions of school life to foster optimal character development (usaha kita secara sengaja dari seluruh dimensi kehidupan sekolah/madrasah untuk membantu pembentukan karakter secara optimal). Pendidikan karakter memerlukan metode khusus yang tepat agar tujuan pendidikan dapat tercapai. Salah satu statetgi dalam pembentukan karater bangsa adalah dengan muatan lokal.

Dari 18 nilai yang dirumuskan oleh Depdikbud pada table 1, sangat jelas bahwa nilai karakter bangsa itu merupakan sikap dan tindakan, bukan hanya pengertian. Maka bila peserta didik sungguh mempunyai nilai itu berarti mereka mempunyai tindakan nyata yang bercirikan karakter bangsa tersebut. Mereka bukan hanya tahu (to know), tetapi mereka melakukannya (to do), dapat hidup dengan orang lain lebih baik (to live together), dan semakin menjadi pribadi yang utuh dan berkembang (to be) (bdk. Delors, J., 1996). Dengan demikian anak didik dibiasakan 
melakukan sesuatu nilai yang baik, yang menjadikan hidupnya makin sempurna. Dengan pembiasaan itu, mereka akan berkembang menjadi pribadi yang utuh, mencintai dan menghormati Tuhan, hidup damai dengan sesama, mengembangkan lingkungan, memajukan diri sendiri, dan gembira sebagai warga bangsa Indonesia (Suparno, 2012:5).

KONSEP KURIKULUM MUATAN LOKAL

Indonesia memiliki keanekaragaman dalam berbagai aspek sosial, budaya, geografis, dan demografis. Akan tetapi memiliki kesatuan yang utuh berkat Pancasila sebagai dasar dan ideologi negara. Bhinneka Tunggal Ika merupakan semboyan sebagai pegangan bangsa Indonesia dalam mewujudkan kesatuan dan keanekaragaman. Indonesia yang terdiri dari berbagai macam suku bangsa yang memiliki keanekaragaman multikultur (adat istiadat, tata cara, bahasa, kesenian, kerajinan, keterampilan daerah, dll) merupakan ciri khas yang memperkaya nilai-nilai kehidupan bangsa Indonesia. Oleh karena itu keanekaragaman tersebut harus selalu dilestarikan dan dikembangkan dengan tetap mempertahankan nilainilai luhur bangsa Indonesia melalui upaya pendidikan. Pengenalan keadaan lingkungan, sosial, dan budaya kepada peserta didik memungkinkan mereka untuk lebih mengakrabkan dengan lingkungannya.

Kurikulum adalah satu komponen penting dari sistem pendidikan, karena merupakan komponen pendidikan yang dijadikan acuan oleh setiap satuan pendidikan, baik oleh pengelola maupun penyelenggara; khususnya oleh guru dan kepala sekolah. Penentuan isi dan bahan pelajaran muatan lokal didasarkan pada keadaan dan kebutuhan lingkungan, yang dituangkan dalam mata pelajaran dengan alokasi waktu yang berdiri sendiri. Hal ini sejalan dengan upaya peningkatan mutu pendidikan nasional.

Menurut Surat Keputusan Menteri Pendidikan dan Kebudayaan Republik Indonesia dengan nomor 0412/U/1987 tanggal 11 Juli 1987 yang dimaksud dengan kurikulum muatan lokal ialah program pendidikan yang isi dan media 
penyampaiannya dikaitkan dengan lingkungan alam dan lingkungan budaya serta kebutuhan daerah dan wajib dipelajari oleh murid di daerah tersebut. Menurut Kurikulum 1994 Kurikulum Muatan Lokal adalah materi pelajaran yang diajarkan secara terpisah, menjadi kajian tersendiri. Tirtarahardja dan La Sula mengungkapkan bahwa kurikulum muatan lokal adalah suatu program pendidikan yang isi dan media dan strategi penyampaiannya dikaitkan dengan lingkungan alam, lingkungan sosial, dan lingkungan budaya serta kebutuhan daerah (Iim Wasliman, 2007: 209). Secara garis besar Kurikulum Muatan Lokal adalah materi pelajaran yang diajarkan secara terpisah yang isi dan media penyampaiannya sesuai dengan ciri khas daerah tertentu. Menurut Mulyasa kurikulum muatan lokal adalah kegiatan kurikuler yang mengembangkan kompetensi yang disesuaikan dengan ciri khas dan potensi daerah, termasuk keunggulan daerah yang materinya tidak dapat dikelompokkan ke dalam mata pelajaran yang ada. (Mulyasa, 2009: 256) Substansi Muatan lokal ditentukan oleh masing-masing satuan pendidikan. Pendapat ini tampaknya menganggap bahwa kurikulum muatan lokal hanya bisa diakomodasi melalui kegiatan yang terpisah dengan mata pelajaran.

Tujuan penyelenggaraan dan pelaksanaan muatan lokal dalam kurikulum yaitu terdiri dari tujuan langsung dan tak langsung. (Abdullah Idi, 1999: 180) Tujuan langsung meliputi bahan pengajaran lebih mudah diserap oleh murid, sumber belajar di daerah dapat lebih dimanfaatkan untuk kepentingan pendidikan, murid dapat menerapkan pengetahuan dan keterampilan yang dipelajarinya untuk memecahkan masalah yang ditemukan di sekitarnya, dan murid lebih mengenal kondisi alam, lingkungan sosial dan lingkungan budaya yang terdapat di daerahnya. Sedangkan tujuan tak langsung meliputi: murid dapat meningkatkan pengetahuan mengenal daerahnya, murid diharapkan dapat menolong orangtuanya dan menolong dirinya sendiri dalam rangka memenuhi kebutuhan hidupnya, dan murid menjadi akrab dengan lingkungan dan terhindar dari keterasingan terhadap lingkungan sendiri. Oleh karena itu untuk 
mencapai tujuan dimana bahan muatan lokal sifatnya mandiri dan tidak terikat oleh pusat, maka peranan guru dalam melaksanakan proses pembelajaran dalam muatan lokal ini sangat menentukan. Untuk melaksanakan pengembangan, langkah-langkah yang ditempuh yaitu menyusun perencanaan muatan lokal, melaksanakan pembinaan, dan merencanakan pengembangan. (Dakir, 2010: 119).

Sekolah berada dalam lingkungan masyarakat. Karena itu program-program sekolah harus disesuaikan dengan lingkungan. Demikian pula pribadi-pribadi yang ada dalam sekolah hidup dalam lingkungan, sehingga perlu diupayakan agar pribadi dapat menyesuaikan diri dan akrab dengan lingkungannya. Adapun fungsi kurikulum muatan lokal diantaranya: 1) Fungsi Integrasi, murid merupakan bagian integral dari masyarakat, karena itu muatan lokal harus merupakan program pendidikan yang berfungsi untuk mendidik pribadipribadi yang akan memberikan sumbangan kepada masyarakat atau berfungsi untuk membentuk dan mengintegrasikan pribadi kepada masyarakat. 2) Fungsi Perbedaan, pengakuan atas perbedaan berarti pula memberi kesempatan bagi pribadi untuk memilih apa yang diinginkannya. Karena itu muatan lokal harus merupakan program pendidikan yang bersifat luwes, yang dapat memberikan pelayanan terhadap perbedaan minat dan kemampuan murid. Ini tidak berarti mendidik pribadi menjadi orang yang individualistik tetapi muatan lokal harus dapat berfungsi mendorong pribadi ke arah kemajuan sosialnya dalam masyarakat.

Ada dua arah pengembangan dalam kurikulum muatan lokal, yaitu: 1) Pengembangan untuk jangka panjang, agar para siswa dapat melatih keahlian dan keterampilan yang sesuai dengan harapan yang nantinya dapat membantu dirinya, keluarga, masyarakat dan akhirnya membantu pembangunan negara. Oleh karena itu perkembangan muatan lokal dalam jangka panjang harus direncanakan secara sedemikian rupa oleh sekolah, keluarga, dan masyarakat setempat dengan perantara pakar-pakar pada instasi terkait baik negeri maupun swasta. Untuk muatan lokal di sekolah dasar 
masih bersifat concentris, kemudian dilaksanakan secara kontinue di sekolah menengah pertama dan akan terjadi konvergensi di sekolah menengah atas. 2) Pengembangan untuk jangka pendek, perkembangan muatan lokal dalam jangka pendek dapat dilakukan oleh sekolah setempat dengan cara menyusun kurikulum muatan lokal kemudian menyusun Indikatornya dan direvisi setiap saat.

Keberhasilan pengembangan kurikulam muatan lokal di sekolah tergantung pada beberapa aspek, yaitu :1) Kekreatifan guru dalam memberikan materi tentang kurikulum mauatan lokal; 2)Kesesuaian program muatan lokal yang diberikan kepada murid; 3) Ketersediaan sarana dan prasarana yang memadai demi kesuksesan pengembangan kurikulum muatan lokal di sekolah tersebut; 4) Cara pengelolaan kurikulum yang baik dan sesuai dengan prosedur; 5) Kesiapan siswa dalam meneriman materi muatan lokal; 6) Partisipasi masyarakat setempat untuk mendukung pelaksanaan kurikulum muatan lokal disekolah tersebut; 7)
Pendekatan kepala sekolah dengan nara sumber dan instansi terkait

$$
\text { Adapun cara menentukan }
$$
bahan pelajaran muatan lokal untuk satu bidang studi dapat dilaksanakan dengan empat cara : 1) Bagi mata pelajaran yang sudah punya SK dan $\mathrm{KD}$, disusun tema dan materi pembelajaran, kemudian dipilih bahan mana yang berkriteria muatan lokal; 2) SK dan KD yang telah dipilih, sesuaikan dengan pola kehidupan masyarakat; 3) Pola kehidupan dalam lingkungan alam, dijadikan sumber sebagai indikator yang mungkin sesuai; 4) Pola kehidupan dalam lingkungan alam, dipilih unsurunsurnya yang perlu dimasukan dalam program pendidikan kemudian dibuat indikator.

Landasan pengembangan muatan lokal adalah keberadaannya sebagai salah satu isi dan struktur kurikulum yang harus diberikan pada tingkat dasar dan menengah. Hal ini sebagaimana tercantum dalam Pasal 37 Undang-Undang (UU) Nomor 20 Tahun 2003 tentang Sistem Pendidikan Nasional, yang menyatakan bahwa Sekolah Dasar dan Menengah terdiri dari mata pelajaran pendidikan agama; 
pendidikan kewarganegaraan, bahasa; matematika; ilmu pengetahuan alam; Ilmu Pengetahuan Sosial; Seni dan Budaya; Pendidikan Jasmani dan Olahraga; Keterampilan/Kejuruan; dan muatan lokal (UU Sisdiknas No. 20 Tahun 2003 Pasal 37 ayat 1).

Selanjutnya, dalam Peraturan Menteri Pendidikan Nasional (Permendiknas) No. 22 Tahun 2006 tentang standar isi menyatakan bahwa Kurikulum Tingkat Satuan Pendidikan (KTSP) selain memuat beberapa mata pelajaran, juga terdapat mata pelajaran muatan lokal yang wajib diberikan pada semua tingkat satuan pendidikan. Kebijakan yang berkaitan dengan dimasukkannya mata pelajaran muatan lokal dalam standar isi dilandasi kenyataan bahwa Indonesia yang terdiri dari berbagai macam suku bangsa yang memiliki keanekaragaman multikultur (adat istiadat, tata cara, bahasa, kesenian, kerajinan, keterampilan daerah) merupakan ciri khas yang memperkaya nilai-nilai kehidupan bangsa Indonesia. Adapun landasan pengembangan muatan lokal tercantum pula pada UU No. 22 Tahun 1999 tentang pemerintahan daerah dan Peraturan pemerintah Republik Indonesia Nomor 19 Tahun 2005 tentang standar nasional pendidikan. (Rusman, 2009:404).

\section{PERAN MUATAN LOKAL DALAM MEMBENTUK}

\section{KARAKTER BANGSA}

Pengembangan muatan lokal dalam membentuk karakter bangsa dapat dilakukan dalam jangka pendek dan jangka jauh. Sedangkan pengembangan muatan lokal dalam jangka pendek dapat dilakukan oleh sekolah setempat dengan cara menyusun kurikulum muatan lokal kemudian menyusun silabusnya dan direvisi setiap saat. Pihak yang memegang peranan cukup penting baik di dalam perencanaan dan pelaksanaan kurikulum adalah guru. Peranan guru bukan hanya menilai perilaku dan prestasi belajar muridmurid dalam kelas, tetap juga menilai implementasi kurikulum dalam lingkup yang lebih luas. Hasil-hasil penilaian demikian akan sangat membantu pengembangan kurikulum, untuk memahami hambatan-hambatan dalam implementasi kurikulum dan juga dapat membantu mencari cara 
untuk mengoptimalkan kegiatan guru (Nana Syaodih S., 2009:157).

Kreativitas guru dalam pelaksanaan pembelajaran menjadi dasar pengembangan muatan lokal yang terinternalisasi tidak hanya untuk peserta didik namun juga bagi pendidiknya. Guru dituntut untuk dapat menggunakan sumber daya ada (lingkungan) dalam pelaksanaan pembelajaran agar pembelajaran menjadi optimal dan kontekstual. Pembelajaran yang kontekstual merupakan salah satu strategi dalam menerapkan muatan lokal di dalam semua materi pembelajaran. Pembelajaran kontekstual dapat menciptakan pembelajaran yang aktif, inovatif, kreatif, efektif dan menyenangkan (PAIKEM) dengan menggunakan berbagai variasi metode, sumber dan alat/ media pembelajaran.

Ira Yumira dalam tulisannya yang berjudul Peran Pendidikan Baca Tulis AL-Quran Sebagai Muatan Lokal Dalam Upaya Membentuk Karakter Kepribadian Siswa Studi di SMP Tri Bhakti Nagreg menunjukkan bahwa apa yang diterapkandari hasil pembelajaran, lebih dari setengahnya $\quad(52 \%)$ responden menyatakan tidak meninggalkan sholat, sebagian kecil (24\%) responden menyatakan patuh pada orang tua, (20\%) menyatakan mengajar mengaji pada adik di rumah, hampir tidak ada (4\%) menyatakan mengajak teman agar mengaji. Hal ini membuktikan bahwa Muatan Lokal Baca Tulis Al-Quran dapat membentuk karakter peserta didik terutama karakter religius yaitu suatu sikap dan perilaku yang patuh dalam melaksanakan ajaran agama dengan tidak meninggalkan sholat. Selain karakter religius ada pula karakter yang sesama manusia dan dirinya sendiri yaitu toleransi, dengan mengajari adik yang bisa ngaji. Disiplin dengan menunjukkan perilaku tertib dan patuh pada waktu belajar ngaji. Rasa ingin tau, Sikap dan tindakan yang selalu berupaya untuk mengetahui lebih mendalam dan meluas dari belajr ngaji. Gemar Membaca, kebiasaan menyediakan waktu untuk membaca Al-Quran.

$$
\text { Penerapan muatan lokal }
$$
bahasa daerah di sekolah yang dilakukan selama ini perlu dipertahankan untuk menjaga bahasa daerah agar tidak punah karena bahasa daerah merupakan identitas 
suatu bangsa. Dalam pelaksanaannya perlu dibuat sebagai mata pelajaran mandiri mengingat karakteristiknya yang tidak dapat diintegrasikan dengan mata pelajaran strategi belajar dan pembelajaran, sebagaimana yang dilakukan Pemerintah Propinsi Jawa Barat. Adapun landasannya, sebagaimana surat edaran Kepala Dinas Pendidikan Propinsi Jawa Barat No. 423/2372/Set-disdik tertanggal 26 Maret 2013 perihal Pembelajaran Muatan Lokal Bahasa Daerah pada Jenjang SD/MI, SMP/MTs, SMA/SMK/MA, dengan demikian pembelajaraan muatan lokal Bahasa Daerah tetap diakomodir dalam Kurikulum 2013 di Jawa Barat dengan pilihan bahasa yaitu Bahasa Sunda, Bahasa Cirebon dan Bahasa Melayu Betawi. (Bambang Sugiharto, 2013).

Hasil penelitian iti Rohmatin Nazilah (2014) tentang implementasi kurikulum muatan lokal bahasa Using sangat berperan dalam upaya pembentukan karakter siswa di SMPN 1 Giri. Kurikulum muatan lokal bahasa Using memiliki penekanan pada wawasan dan pengembangan ilmu pengetahuan, tetapi juga menekankan pada pembentukan dan pembinaan karakter siswa melalui penguatan terhadap nilai-nilai kebudayaan hasil warisan leluhur. Jadi dapat disimpulkan penelitian ini dapat membentuk peserta didik yang dapat menguasai kebudayaan dan bahasa Using secara mendalam dan merupakan landasan dasar dalam membangun kehidupan manusia yang berkarakter luhur.

Sedangkan pengembangan jangka jauh dilaksanakan secara berurutan dan berkesinambungan dari berbagai muatan lokal yang pernah ada di jenjang sekolah dasar sampai menengah, seperti yang dilakukan oleh Kepala Dinas Tenaga Kerja dan Transmigrasi Nusa Tenggara Barat, dengan berupaya menerapkan kurikulum muatan lokal melalui peningkatan kemampuan berbahasa Inggris. Hal ini senada yang dilakukan di DKI Jakarta, bahwa pengembangan kurikulum 2013 semakin menambah sarat pentingnya muatan lokal di sekolah, seperti yang diungkapkan dalam replubika.co.id (Desember, 2013) Kepala Dinas Pendidikan DKI Jakarta Taufik Yudi Mulyanto menekankan bahwa bahasa Inggris akan dijadikan muatan lokal dalam kurikulum baru. "Jadi, di 
Jakarta, bahasa Inggris justru akan menjadi mata pelajaran wajib sebagai tambahan dari desain minimal yang ditawarkan Pusat. Begitu juga dengan Penjaskes." Hal ini menunjukkan bahwa muatan lokal bahasa Inggris perlu diterapkan dalam membentuk karakter siswa yang mandiri, karena Indonesia adalah negara yang tergabung dalam MEA dalam menghadapi arus globalisasi peserta didik sudah harus siap bersaing dengan negara ASEAN yang lain.

Perkembangan muatan lokal dalam jangka jauh dapat dilaksanakan dengan pola Trikon teori oleh $\mathrm{Ki}$ Hajar Dewantara yaitu konsentris, kontinyu dan konvergensi dalam muatan lokal seperti yang diuraikan dalam jurnal humaniora oleh Nunung Sri Wahyuni (2013) menjelaskan pengembangan muatan lokal melalui membatik di SMA Situbondo, hasil penelitiannya menyatakan bahwa penetapan muatan lokal membatik merupakan keputusan sekolah dengan tujuan mensukseskan program pemerintah kabupaten Situbondo melestarikan dan mengembangkan budaya lokal khususnya batik situbondo, memberikan bekal keterampilan, dan peluang usaha.
Selain itu implementasi muatan lokal membatik terlaksana secara optimal serta minat wirausaha siswa tinggi setelah mengikuti mulok membatik.

Hasil penelitian Dr. Tri hartiti Retnowati (2010) tentang membangun karakter siswa melalui pembelajaran batik di sekolah mengatakan bahwa Pembelajaran batik merupakan pelaksanaan pendidikan seni di sekolah diberikan karena keunikan, kebermaknaan dan kebermanfaatan terhadap kebutuhan perkembangan peserta didik, yang terletak pada pemberian pengalaman estetik dalam bentuk kegiatan berekspresi/berkreasi dan berapresiasi. Pengalaman estetik yang diberikan pada pembelajaran batik pada prinsipnya berfungsi melatih dan mengembangkan kepekaan rasa . Dengan kepekaan rasa yang tinggi mental seseorang cenderung mudah diisi dengan nilai-nilai hidup dan kehidupan, seperti nilai religius, nilai moral, nilai budi pekerti ( melatih disiplin, teliti, sabar, bersih, dll). Dengan demikian membangun karakter siswa dengan pembelajaran batik dapat dilaksanakan melalui kegiatan sekolah dan proses pembelajaran di kelas, sehingga 
pembelajran batik di sekolah dapat sebagai sarana membangun karakter siswa untuk membentuk insan yang berkualitas.

Muhammad Nur Farid dalam jurnal komunitas Unnes (2012) mengkaji bagaimana

pelaksanaan muatan lokal batik tulis Lasem pada tingkat sekolah dasar di Kecamatan Lasem sebagai bentuk pelestarian budaya lokal. Hasil penelitian ini menunjukkan pelaksanaan muatan lokal batik tulis Lasem pada kelas empat dan kelas lima. Muatan lokal tersebut berhasil menanamkan kepedulian dan kecintaan anak-anak pada batik tulis Lasem. Hal ini menunjukkan bahwa muatan lokal batik tulis mampu membentuk karakter peserta didik yang kreatif dan cinta tanah air, mereka cinta dengan produk Indonesia. Mereka berusaha melestarikan kebudayaan Indonesia dengan belajar. Contoh lain dalam pengembangan muatan lokal jangka jauh adalah penetapan keluasan waktu belajar dalam pelaksanaan muatan lokal di Surabaya dengan menetapkan Jumat Jawa (JJ). DKI Jakarta sebagai ibukota negara Indonesia juga telah menerapkan muatan lokal dengan menetapkan pakaian daerah untuk dipakai guru sebagai langkah memperkenalkan dan menumbuhkan kecintaan pada budaya daerah.

$$
\text { Dalam pengembangan }
$$

selanjutnya ada dua hal yang perlu diperhatikan yaitu perluasan muatan lokal dan pendalaman muatan lokal. Perluasan muatan lokal pada dasarnya ialah bahan muatan lokal yang ada di daerahnya itu yang terdiri dari berbagai jenis muatan lokal. Sedangkan pendalaman muatan lokal adalah bahan muatan lokal yang sudah ada kemudian diperdalam sampai lanjutan. Perluasan dan pendalaman muatan lokal yang dimaksud salah satunya dengan penguasaan bahasa daerah selain bahasa asing. Melalui muatan lokal seperti yang diungkapkan Kompas (26 Maret 2015) adalah sebagian bahasa daerah di Nusantara semakin terancam punah, terutama akibat minimnya tradisi pengajaran lintas generasi. Hal ini merugikan bangsa Indonesia karena keanekaragaman bahasa, sebagai salah satu unsur penting pembentuk kebudayaan, menjadi semakin berkurang. Salah satu cara yang wajib ditempuh adalah dengan mengembangkan muatan 
lokal bahasa daerah sebagai wujud penanaman nilai budaya daerah.

Penanaman 18 Nilai Karakter sangat dianjurkan terutama penanaman nilai karakter cinta tanah air. Banyak sekali budaya lokal Indonesia yang terancam punah bahkan diakui oleh negara lain. Pendidikan Nilai karakter harus dijalankan banyak pihak, antara lain orang tua, sekolah, masyarakat, dan negara. Di beberapa negara yang berdasarkan agama, pendidikan menjadi tanggungjawab orang tua, sekolah, instansi agama, masyarakat, dan negara. Demikian juga dengan pendidikan karakter bangsa juga menjadi tanggungjawab beberapa pihak, seperti orang tua, sekolah, masyarakat, dan Negara (Ryan \& Lickona, 1992).

\section{KESIMPULAN}

Dalam mewujudkan karakter bangsa yang kuat di era globalisasi ini dengan cara menerapkan kurikulum muatan lokal. Bangsa Indonesia merupakan bangsa yang memiliki aneka ragam budaya. Budaya tersebut harus terus dilestarikan dan diperkuat melalui pengembangan kurikulum. Salah satu caranya pengembangan kurikulum yang dilakukan adalah dengan pengembangan kurikulum muatan lokal dimana karakteristik dan ciri daerah ditingkatkan dan penguasaan akan pengetahuan global juga dioptimalkan. Muatan lokal dapat menumbuhkan kecintaan peserta didik sebagai penerus bangsa akan nilai-nilai sosio kultural daerahnya dan negerinya. Selain itu nilai moral yang terkandung pada setiap daerah dapat ditumbuhkan dalam diri peserta didik maupun pendidik. Sehingga terwujudlah karakter bangsa sesuai dengan budaya lokal.

Untuk mewujudkan karakter bangsa yang ideal kepada peserta didik melalui kerukulum muatan lokal, diperlukan penelitian yang mendalam. Penelitian akan membantu terwujudnya program pendidikan yang tepat, efektif, efisien dan pengembangan karakter peserta didik. Pembangunan karakter bangsa perlu diperhatikan demi terwujudnya masyarakat Indonesia yang aman, bermartabat dan sejahtera, maka masih banyak persoalan yang diteliti, sehingga dapat diambil langkah yang positif. 


\section{DAFTAR PUSTAKA}

Dakir, Haji. (2010). Perencanaan dan Pengembangan Kurikulum. Jakarta: Rineka Cipta.

Delors, J. (1996). Learning: The Treasure Within. Paris: UNESCO Publishing

Idi, Abdullah. (1999). Pengembangan Kurikulum: Teori dan Praktik. Jakarta: Gaya Media Pratama.

Iim Wasliman. (2007). Modul Problematika Pendidikan Dasar. Bandung: Pps Pendidikan Dasar UPI.

Kompas. (2012). Bahasa Daerah Terancam: Sebagian dari 749 Bahasa di Nusantara kian Kehilangan Penutur. Maret 2015, halaman 12. Jakarta.

Mulyasa, E. (2009). Implementasi Kurikulum Tingkat Satuan Pendidikan, Kemandirian guru dan Kepala Sekolah, Cetakan Ketiga, Jakarta: PT Bumi Aksara.

Nur Farid, Muhammad. (2012). Peranan Muatan Lokal Materi Batik Tulis Lasem Sebagai Bentuk Pelestarian Budaya Lokal. Jurnal Komunitas (Research And Learning In Sociology And Anthropologhy), 4(1) Http://Journal.Unnes.Ac.Id/ $\mathrm{Nj}$ u/Index.Php/
Komunitas/Article/View/2400

Rachman Taufik. (2012). Pengamat: Bahasa Inggris Jadi Muatan Lokal Saja http://www.republika.co.id/ber ita/pendidikan/beritapendidikan/12/10/22/ mca72 pengamat-bahasa-inggris-jadimuatan-lokal-saja, diakses 19 Januari 2016.

Rusman. (2009). Manajemen Kurikulum. Jakarta: Rajawali Pers.

Ryan, K. \& Lickona, T. (1992). Character Development in Schools and Beyond. Washington, D.C.: The Council for Research in Values and Philosophy.

Sugiharto, Bambang. (2013). Penerapan Bahasa Daerah pada Kurikulum 2013 di Jawa Barat http://bahasa.kompasiana.com/ 2013/11/28/penerapan-bahasadaerahpada-kurikulum-2013di-jawa-barat-613871.html, diakses 19 Januari 2016.

Suparno, P. (2012). Sumbangan Pendidikan Fisika terhadap Pembangunan Karakter Bangsa. Pidato Pengukuan Guru Besar. Yogyakarta: USD. 